No. 4080 January 10, 1948

and compressed-limit control charts. The necessary tables with instruction sheets containing fully worked out examples are given in a further section, and a bibliography is appended.

\section{Air-depolarized Primary Cells}

British Standard Specification No. $1335 ; 1946$ (Publications Sales Department, British Standards Institution, 28 Victoria Street, London, S.W.1. $2 s$. post paid) prescribes the minimum rating of airdepolarized-type primary cells on continuous discharge and gives the methods of test on which the rating is based. An air-depolarized cell is defined as a primary cell with two electrodes, one mainly of carbon and the other of zinc, in an electrolyte of ammonium chloride, or other salts, or caustic soda, and in which the depolarization is mainly effected by air, to which free access must be given. A nomen. clature is prescribed for the designation of the cells, a letter representing the type, and a number the size of cell. The letter code to be used consists of : $A, D, W, R, S$, and $C$, for air-depolarized, dry, wet, round, square and caustic soda, cells respectively. The quality of the materials to be used, the dimensions of the electrodes, containers, connecting wires and terminals of the cells are also specified in detail.

\section{Rubber Technology Conference}

IN 1938 the Institution of the Rubber Industry organised an International Rubber Technology Conference in London. It was the intention of the Institution to organise another conference within the following two or three years ; but it has been necessary to wait ten years. A conference will accordingly be held at the Central Hall, Westminster, London, S.W.1, during June 23-25. .The Conference will cover the following subjects : natural and synthetic rubber lattices; chemistry of rubber; physics of rubber; testing and analysis ; synthetic rubbers ; compounding ingredients; fibres and textiles; developments in factory processes and products since 1938. Invitations to attend the Conference have been sent to well-known technologists all over the world, many of whom have already promised papers. All the papers and full details of the Conference will be published in a volume entitled "The Proceedings of the Rubber Technology Conference, London, 1948', a copy of which will be issued free to all those enrolling for the Conference; extra copies will be available for sale generally at $£ 22 s$. each. Application forms and details can be obtained from the Conference Secretary, Institution of the Rubber Industry, 12 Whitehall, London, S.W.1, who is prepared to assist in obtaining hotel accommodation.

\section{University of London: Appointments}

THE following appointments in the University of London have been announced:

Mr. G. E. H. Foxon, lecturer in zoology and comparative anatomy at University College, Cardiff, to the University readership in biology tenable at Guy's Hospital Medical School as from April 1.

The following titles have been conferred : professor of bacteriology in the University on Lord Stamp, in respect of the post held by him at the Postgraduate Medical School of London; professor of biology in the University on Dr. J. H. Woodger, in respect of the post held by him at Middlesex Hospital Medical School; reader in surveying in the University on Mr. Alfred Stephenson, in respect of the post held by him at the Imperial College of Science and Technology.

The degree of doctor of science has been conferred on Mr. F. W. Andrews (Birkbeck College).

\section{Colonial Service : Appointments}

THE following appointments have been macie in the Colonial Service: P. A. Greig, agricultural development officer, Nigeria; W. G. Brookbank, agricultural officer, Tanganyika; D. H. Drennan, agricultural officer, Tanganyika; N. B. Flockhart, agricultural officer, North Borneo; R. Henderson, agricultural officer, Malaya; W. J. C. Little, agricultural officer, Nigeria; R. R. Mason, agricultural officer, Fiji ; D. G. Thomas, botanist, Uganda ; I. H. Warren, agricultural chemist, Tanganyika; J. R. Williams, entomologist, Mauritius; D. W. Winter, agricultural officer, Zanzibar; R. S. Ayliffe, assistant conservator of forests, Trinidad; J. A. D. Jackson, assistant conservator of forests, Nigeria; J. A. Laurenson, assistant conservator of forests, Sierra Leone/Gambia; F. J. S. Phillips, assistant conservator of forests, Nigeria; A. W. M. Watt, assistant conservator of forests, Uganda; D. A. J. Wood, assistant conservator of forests, Gold Coast ; J. R. Harpum, geologist, Tanganyika; H. R. Threlfall, surveyor, Tanganyika; D. L. Johns, research officer (entomologist), Tanganyika; A. F. MacKenzie (agricultural officer, Sierra Leone), senior agricultural officer, Sierra Leone; J. F. Ward (agricultural officer, Kenya), senior agricultural officer, Nigeria ; F. A. Cassidy (inspector of mines, Sierra Leone), senior inspector of mines, Nigeria.

\section{Announcements}

The Council of the Linnean Society of London has nominated the following as recipients of the Trail Award and Medal : for 1942, Dr. Honor B. Fell, of the Strangeways Laboratory, Cambridge; for 1947, Dr. C. D. Darlington, director of John Innes Horticultural Institution. The Trail Award and Medal was established by a donation by the late Prof. J. W. H. Trail "to encourage study that throws light on the substance known as Protoplasm, or the physical basis of life" and is awarded by the Council at intervals of not less than five years. The presentations of the Award and Medal will be made at the Society's anniversary meeting on May 24.

H. B. Henbest has been elected to a Beit Fellowship for Scientific Research of the value of $£ 400$ a year, tenable at the Imperial College of Science and Technology, London, for research in organic chemistry under the direction of Sir Ian Heilbron.

THE late Dr. Collinge's collection of terrestrial Isopoda has been presented to the Yorkshire Museum, to which institution all future inquiries with regard to the collection should be addressed. The collection is important since it contains a large number of Collinge's described species and varieties. A list will be supplied on loan to any interested worker on application to the Keeper, Yorkshire Museum, York.

Erratum.-Referring to the communication on the 'floating thread' in Nature of November 15, 1947, p. 673, I. Kuščr writes : "The formula at the bottom of the left-hand column should be $d=\pi\left(\sigma_{0}-\sigma_{1}\right)^{2}$ $\div 4 \mu \rho v_{0}{ }^{3}$. In both expressions for $y$ (right-hand column) substitute 1 for $\lambda$. The unit 'cm.' against the value for the derivative $(d y / d x)_{0}$, which is obviously dimensionless, should be omitted." 